\title{
PENGARUH PENERAPAN UNIT LAYANAN PENGADAAN (ULP) TERHADAP EFISIENSI DAN EFEKTIFITAS PENGADAAN BARANG/JASA PADA PEMERINTAH PROPINSI PAPUA
}

\author{
Novijanti A. R. Temaluru ${ }^{5}$ \\ novijanti.temaluru@gmail.com \\ Meinarni Asnawi ${ }^{2}$ \\ meinarni.asnawi@gmail.com \\ Syaikhul Falah ${ }^{3}$ \\ sehufalah@gmail.com
}

\begin{abstract}
The objective of this research was to assess and analyse the effect of duties and responsibilities to efficiency and effectiveness of budgets in Procurement Service Units (PSU). The number of research population in this study was 161 participants of whom were the employees of the formed Team Work. A purposive sampling technique was employed to determine that the 50 respondents selected. Data collections were conducted through direct survey. To test research hypotheses, a multiple regression was applied to find empirical results. The results showed that in partial the PSU positively associated with efficiency and effectiveness of budgets in Papua province. This inferred that the first hypothesis was supported. Furthermore, the responsibilities of PSU significantly associated with the level of efficiency and effectiveness of budgets in Papua province. Hence, the second hypothesis was supported. This study was also revealed that duties and responsibilities simultaneously associated with the level of efficiency and effectiveness of budgets in Papua province.
\end{abstract}

Key words: Duties, Responsibilities, Efficiency and Effectiveness of Budgets

\section{PENDAHULUAN}

Dalam rangka melaksanakan ketentuan pasal 14 dan pasal 130 ayat (1) Peraturan Presiden Nomor 70 Tahun 2012 dimana Pemeritah

5 Alumni Mahasiswa Magister Keuangan Daerah

2 Staf dosen Jurusan Akuntansi Fakultas Ekonomi dan Bisnis Universitas Cenderawasih dan Ketua Program Magister Akuntansi Universitas Cenderawasih

3. Staf dosen Jurusan Akuntansi Fakultas Ekonomi dan Bisnis Universitas Cenderawasih 
wajib membentuk Unit Layanan Pengadaan (ULP) paling lambat Tahun Anggaran 2014, maka Pemerintah Provinsi Papua membuat Surat Keputusan Gubernur Provinsi Papua.Surat Keputusan (SK) Gubernur Provinsi Papua Nomor 188.4/49/Tahun 2014 tentang Pengangkatan Perangkat Organisasi dan Penetapan Tunjangan dimana Pemerintah Provinsi Papua berkomitmen untuk membentuk Unit Layanan Pengadaan (ULP) sesuai yang telah diamanatkan dalam peraturan Presiden. Adapun pembentukan ULP secara fungsional melaksanakan tugas dan fungsi di bidang pengadaan barang/jasa.

Pembentukan ULP ini dilakukan karena merupakan amanat dari Perpres dan juga karena Pengadaan barang/jasa merupakan indikator penting tentang penerapan Good governance dan indikator kualitas kinerja pelayann publik. Pengadaan barang/jasa pemerintah yang melibatkan pemerintah sebagai pengguna barang/jasa, pihak swasta sebagai penyedi barang/jasa dan masyarakat sebagai pihak penerima manfaat merupakan perwujudan nyata dari penerapan good governance.

Hal ini sejalan dengan kajian yang dilakukan oleh Udoyono, (2012) hasil kajian membuktikan bahwa: pertama, dimensi fisibilitas harus memenuhi nilai kelayakan seperti adanya regulasi yang menjamin terlaksananya E-Procurement, adanya dukungan pelembagaan EProcurement, adanya dukungan dari stakeholder terhadap implementasi E-Procurement, dan adanya dukungan masyarakat terhadap pelaksanaan E-Procurement. Keduadimensi akuntabilitas meliputi belum adanya pertanggungjawaban regulasi dari proses pengadaan barang dan jasa, pertanggungjawaban secara politik masih bersifat internal pemerintahan, dan bertanggungjawaban secara keuangan masih tertutup.

Kajian diatas didukung oleh kajian yang dilakukan Damayanti dan Hamzah, (2010) dimana hasil kajian membuktikan bahwa secara parsial variabel efisiensi dan transparansi berpengaruh secara signifikan terhadap good governace, sedangkan efektifitas, daya saing dan 
tanggung jawab tidak berpengaruh secara signifikan terhadap good governace. Sedangkan secara semultan hasil kajian menunjukan variabel efisiensi, efektifitas, dan saing dan transparansi dan tanggung jawab berpengaruh secara signifikan terhadap good governance.

Dalam prakteknya pengadaan barang/jasa pemerintah ini masih ditemukan banyak permasalahan di instansi memiliki peluang yang besar untuk terjadinya penyelewengan. Penyelewengan dapat berupa menaikkan nilai proyek dari nilai yang sebenarnya, tidak melakukan prosedur pelelangan yang ditetapkan oleh peraturan dan pengadaan barang/jasa fiktif.

Fenomena yang terjadi dalam pembentukan ULP di Indonesia juga memiliki beberapa tantangan,masalah terbesar adalah soalpolitical will, kemauan yang kuat dari kepala instansiatau kepala daerah untuk membentuk ULP."Ongkos politik untuk menjadi kepala daerah dinegeri ini cukup besar. Sehingga ketika terpilih,kepala daerah tadi ingin uangnya kembali. Salahsatunya dengan meng-abuse pengadaan. Otomatisdia akan enggan untuk membangun sebuahpengadaaan yang independen," kata Prabowo dalam (Kredibel, 2012).masalah insentif bagi pelaksana kegiatan kegiatanpengadaan yang masih belum cukup memadai.

Fenomena ini sejalan dengan fenomena yang terjadi di Provinsi Papua dimana sebelum pembentukan ULP panitia lelang pada masingmasing SKPD terkadang tidak dapat dikontrol dengan baik dan tidak diketahui dengan pasti seberapa besar penghematan anggaran yang dilakukakan. Namun dengan terbentuknya ULP lebih transparan dan terbuka dalam arti bahwa seberapa besar penghematan/efisiensi anggaran yang dilakukan dapat diketahui dengan pasti

Berdasarkan fenomena diatas dapat dijelaskan bahwa walaupun tugas dan kewenangan yang dilakukan oleh Unit Layanan Pengadaan (ULP) Propinsi Papua belum dikatakan sudah berjalan secara maksimal namun hasil penerapan ULP di Propinsi Papua sudah menunjukan adanya efisiensi anggaran sebesar $3.8 \%$ hal tersebut menunjukan bahwa 
lebih ditingkatkan lagi tugas dan kewenangan Unit Layanan Pengadaan (ULP) Propinsi Papua sehingga mampu menguranggi kebocoran atau pemborosan anggaran pemerintah.

Fenomena yang bersinggungan langsung dengan pengadaan barang dan jasa ini adalah kasus-kasus korupsi yang marak terjadi baik yang ditangani oleh Komisi Pemberantasan Korupsi (KPK) maupun Komisi Pengawas Persainagan Usaha (KPPU). Sebanyak 24 dari 33 kasus atau 77 persen kasus yang ditangani KPK merupakan kasus tindak pidana korupsi yang berhubungan dengan pengadaan barang dan jasa pemerintah. Berdasarkan sejumlah kasus yang ditangani KPPU terdapat pelanggaran asas persaingan usaha yang sehat yang pada akhirnya merugikan negara. Baik KPK maupun KPPU mengindikasikan pelanggaran yang muncul dari kelemahan dalampengadaan barang dan jasa pemerintah.

Selain itu, kajian Indonesian Corruption Watch (ICW) pada tahun 2005, mengungkapkan, bahwa mekanisme pelaksanaan proyek yang memberikan keistimewaan kepada salah satu pihak melalui penunjukan langsung dianggap oleh pejabat tinggi bukan merupakan pelanggaran yang serius. Terdapat 43 kasus yang terindikasi korupsi di sektor pengadaan, yang modusnya menggunakan penunjukan langsung berdasarkan temuan ICW. Selain indikasi korupsi yang terjadi dengan melakukan penunjukan langsung, modus korupsi lain yang sering terjadi pada proses pengadaan adalah praktik mark-up (48 kasus), pemerasan (50 kasus), penyimpangan kontrak (1 kasus), dan proyek fiktif (8 kasus). Modus penyimpangan yang banyak terjadi pada sektor pengadaan ini menunjukkan sistem akuntabilitas dan transparansi masih belum memadai. Di samping itu, sistem pencegahan yang ada saat ini belum berjalan secara efektif untuk meminimalisasi praktik penyimpangan di sektor tersebut.

Berdasarkan kondisi yang ada, kehadiran suatu lembaga diperlukan untuk melakukan pengkajian yang dilaksanakan dengan 
menganalisis kebijakan dan merumuskan sistem pengadaan barang dan jasa. Lembaga tersebut juga bertugas menyusun kebijakan yang dilaksanakan dengan merumuskan sistem, prosedur, dan penetapan standar pengadaan barang dan jasa. Selain itu, lembaga tersebut memiliki kewenangan dalam pengembangan dan pembinaan sumber daya manusia, pelayanan bimbingan teknis, pemberian pendapat, rekomendasi, dan koordinasi penyelesaian masalah, pemantauan implementasi kebijakan, dan pengawasan. Pengembangan sumber daya manusia menjadi penting karena berkaitan dengan pelaku pengadaan yang hanya sebagaian kecil yang professional, baik sebagai pelaku proses, pemasok, maupun pelaksana. Sepanjang pelaksanaan pengadaan barang dan jasa tidak professional, sulit mewujudkan good governance di bidang pengadaan barang dan jasa akibat pelaku belum mampu menerapkan prinsip pengadaan barang dan jasa secara utuh.

Berdasarkan uraian hasil kajian-kajian empiris yang telah dikemukakan, maka tujuan penelitian ini adalah untuk menguji dan menganalisis pengaruh tugas dan wewenang tehadap efisiensi dan efektifitas anggaran pada Unit Layanan Pengadaan (ULP) di Provinsi Papua

\section{METODE PENELITIAN}

\section{Kerangka Konseptual dan Hipotesa}

Kerangka konseptual penelitian ini dibangun dengan didasarkan pada fenomena-fenomena masalah yang terjadi, keselarasan dengan tujuan penelitian yang hendak dicapai, keterkaitan antar variabel terteliti secara teoritis dan kajian penelitian-penelitian sebelumnya serta metodologi serta yang digunakan. Kerangka konseptual penelitian ini diharapkan dapat menggambarkan tentang penelitian yang akan dilakukan penulis secara keseluruhanpengaruh tugas dan wewenang Unit Layanan Pengadaan (ULP) terhadap efisiensi dan efektivitas anggaran Provinsi Papuaseperti yang terlihatdibawah ini; 


\section{Gambar 1}

Model Penelitian

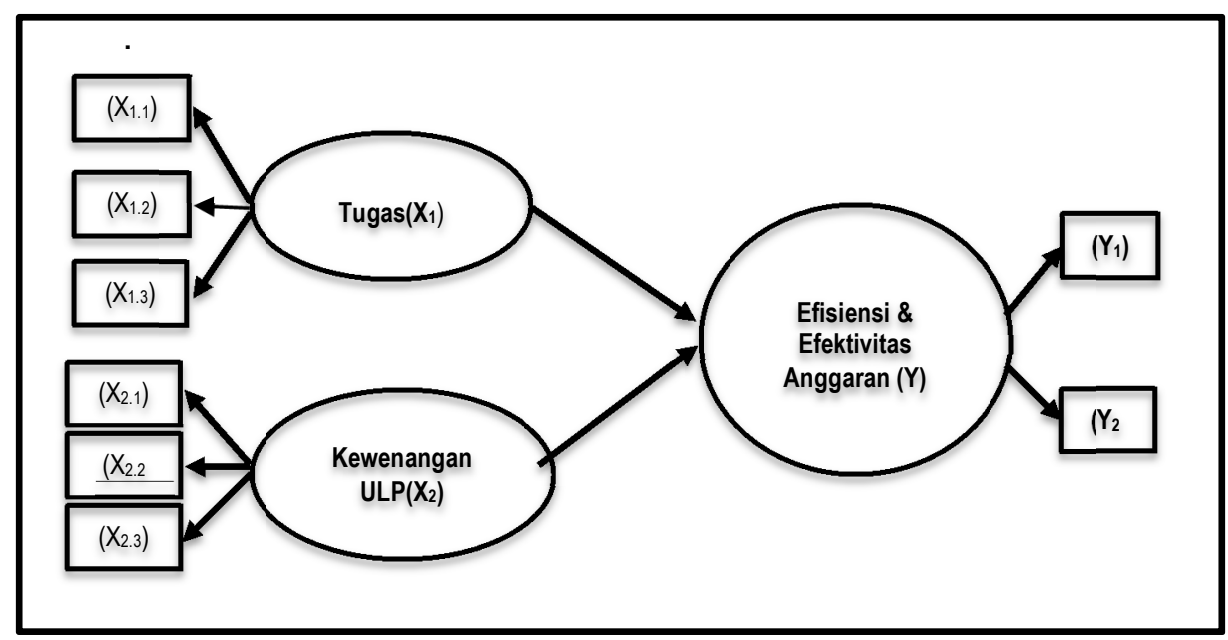

Sumber: data diolah (2015)

Hipotesis penelitian mengenai peran pembentukan Unit Layanan Pengadaan (ULP) terhadap efisiensi anggaran yang dikemukakan adalah;

$\mathrm{H}_{1}$ : Diduga tugas ULP berpengaruh terhadap efisiensi dan efektivitas anggaran pada Unit Layanan Pengadaan (ULP) Pemerintah Provinsi Papua.

$\mathrm{H}_{2}$ :Diduga wewenangULP berpengaruh terhadap efisiensi dan efektivitas anggaran pada Unit Layanan Pengadaan (ULP) Pemerintah Provinsi Papua.

$\mathrm{H}_{3}$ : Diduga secara simultan tugas dan wewenang ULP berpengaruh terhadap efisiensi dan efektivitas anggaranpada Unit Layanan Pengadaan (ULP) Pemerintah Provinsi Papua.

\section{Desain Penelitian}

Pendekatan dalam penelitian ini termasuk dalam penelitian kuantitatif, model penelitiannya adalah model survei dengan menggunakan instrument kuesioner. Penelitian ini dilakukan pada Kantor Unit Pelayanan Pengadaan (ULP) Pemerintah Provinsi Papua.Lokasi 
penelitian berada pada Kantor ULP yang berada dibawah Sekretaris Daerah Provinsi Papua, Kantor Gubernur Provinsi Papua.

\section{Populasi dan Sampel Penelitian}

Populasi dalam penelitian ini adalah Unit Layanan Pengadaan barang/jasa Pemerintah Provinsi Papua. Data sekunder tentang jumlah staf ULP diperoleh dari Sekretariat Daerah Provinsi Papua. Jumlah staf ULP sebanyak 9 (sembilan) orang yang terdiri dari 1 (satu) orang Kepala ULP, 1 (satu) orang Sekretris ULP, 2 (dua) orang administrasi keuangan, 3 (tiga) orang administrasi surat masuk dan keluar dan 2 (dua) orang kemanan kantor. Dan ditambah dengan Kelompok Kerja (POKJA) sebanyak 161 (seratus enam puluh satu) orang yang diambil dari beberapa instansi, seperti Dinas PU Provinsi Papua, Dinas Perhubungan Provinsi Papua, Dinas Kesehatan Provinsi Papua, Dinas Perkebunan Provinsi Papua, Dinas Pertambangan Provinsi Papua, Dinas Kelautan dan Perikanan Provinsi Papua, Dinas Peternakan Provinsi Papua, RSUD Jayapura, Biro Umum Setda Provinsi Papua, BAPEDA Provinsi Papua dan RSJ Abepura.

Teknik penarikan sampel yang digunakan dalam penelitian ini menggunakan metode probability sampling. sementara teknik penarikan sampel yang digunakan adalah teknik purposive sampling, dengan kriteria penarikan sampel sebagai berikut;

1. Responden memenuhi kriteria pokja sebesar 150 responden

2. Responden masih aktif sampai dengan tahun 2015 sebesar 50 responden

Berdasarkan kriteria tersebut maka sampel penelitian yang berhasil dimintai informasi untuk keperluan pengolalan data adalah sebanyak 50 responden. Jika melihat besarnya ukuran sampel minimal yakni 30 (Sekaran, 2006) maka jumlah sampel penelitian ini dinilai layak untuk dianalisis lebih lanjut. 


\section{Definisi Operasional}

Definisi operasional merupakan indikator-indikator yang dibutuhkan dalam penelitian yang akan digunakan untuk mendeskripsikan hal-hal yang akan diteliti, yaitu;

1. Tugas ULP

Tugas ULP adalah keseluruhan proses yang dimulai dari tahapan awal perencanaan pengadaan, penyediaan sumber daya (penyedia, barang/jasa, pasar, dan aktivitas pokja ULP), penentuan metode pemilihan, kriteria penilaian sampai dengan administrasi kontrak yang pembiayaannya sebagian atau seluruhnya bersumber dari APBD. Variabel ini terwakili 3 indikator yang diadopsi dari Peraturan Kepala LKPP No. 5 Tahun 2012, yakni; tugas kepala ULP, tugas tatausahaan/sekretariat ULP dan tugas kelompok kerja (pokja) ULP yang selanjutnya dijabarkan pada 15 item pernyataan. Pengukuran variabel ini menggunakan skala likert yang dimulai dengan dari sangat tidak setuju dengan skor 1 hingga sangat setuju dengan skor 5 .

2. Wewenang ULP

Kewenangan ULP sebagaimana dimaksud dalam pasal 7 Peraturan Kepala LKPP No. 5 Tahun (2012) mencakup pelaksanaan pengadaan barang/jasa yang pembiayaannya sebagian atau seluruhnya bersumber dari APBD. Variabel ini terwakili 3 indikator yang diadopsi dari Peraturan Kepala LKPP No. 5 Tahun 2012 seperti yang disebutkan diatas, yakni; wewenang penetapan, wewenang pengusulan dan wewenang pemberian sanksi. Selanjutnya indikator tersebut dijabarkan pada 13 item pernyataan. Pengukuran variabel ini menggunakan skala likert yang dimulai dengan dari sangat tidak setuju dengan skor 1 hingga sangat setuju dengan skor 5

3. Efisiensi dan efektivitas anggaran

Suatu kegiatan dapat disebut efisien jika usaha yang telah dilakukan, memberikan output yang maksimum, baik dari jumlah maupun 
kualitas maupun kuantitas (Gie dan Thoha, 1978). Variabel ini terwakili 2 indikator yang diadopsi dari Wijaya, indriani, dan Putri, (2009) yakni; efiensi biaya dan efisiensi waktu yang selanjutnya dijabarkan pada 8 item pernyataan. Pengukuran variabel ini menggunakan skala liket yang dimulai dengan dari sangat tidak setuju dengan skor 1 hingga sangat setuju dengan skor 5 .

\section{Uji Instrumen Penelitian}

\section{Uji Validitas}

Uji validitas menunjukan sejauh mana tingkat efektivitas alat pengukur didalam melakukan pengukuran (Agusty, 2006). Uji validitas dalam penelitian ini menggunakan rumus korelasi Product Moment Person, dimana valid atau tidaknya instrumen dapat diketahui dengan membandingkan indeks korelasi Product Moment Person dengan signifikan 5\%. Artinya bila probabilitas hasil korelasi lebih kecil dari 0,05 maka instrumen dinyatakan tidak valid dan sebaliknya, jika hasil korelasi lebih besar dari 0,05 maka instrumen dinyatakan valid. Formula korelasi Product Moment Person adalah sebagai berikut;

$$
r=\frac{n \sum X Y-\sum X \sum Y}{\sqrt{n \sum X^{2}-\left(\sum \llbracket X\right)^{2} \rrbracket\left[n \sum Y^{2}-\left(\sum Y\right)^{2}\right]}}
$$

Keterangan;

$$
\begin{aligned}
& \mathrm{n}=\text { Banyaknya sampel } \\
& \mathrm{X}=\text { Nilai atau skor } \mathrm{X} \\
& \mathrm{Y}=\quad \text { Nilai atau skor } \mathrm{Y}
\end{aligned}
$$

\section{Reliabilitas}

Reliabilitas adalah indeks yang menunjukan sejauh mana suatu alat ukur dapat dipercaya atau diandalkan. Dalam penelitian ini, pengujian reliabilitas menggunakan Alpha cronbachs. Menurut Arikunto, (2003)rumus digunakan untuk mencari reliabilitas 
instrumen yang skornya bukan 1 dan 0 , misalnya angket atau soal bentuk uraian. Dengan rumus sebagai berikut;

$\mathrm{r} 11=\left(\frac{\boldsymbol{k}}{\boldsymbol{k}-1}\right)\left(1-\frac{\sum \delta b^{2}}{\delta 1^{2} t}\right)$

Keterangan;

$\mathrm{r} 11=$ Reliabilitas Instrumen

$\mathrm{k}=$ Banyaknya butir pernyataan atau banyaknya soal

$\sum \sigma^{2} b=$ Jumlah varaians butir

$\sigma 1^{2}=$ Varians total

Suatu instrumen dapat dikatakan reliabel jika memiliki nilai koefisien keandalan lebih besar atau sama dengan 0,6.

\section{Pengujian Asumsi Klasik}

\section{Uji Normalitas}

Tujuan asumsi normalitas data adalah untuk menguji apakah variabel independen dan variabel dependen, atau keduanya dalam suatu model regresi berdistribusi normal atau tidak. Model regresi yang baik jika data variabelnya berdistribusi mendekati normal atau normal sama sekali (Sunyoto, 2012). Salah satu cara untuk mendeteksi normalitas data adalah dengan menggunakan normal probability plot yang pada prinsipnya suatu data ril dikatakan berdistribusi normal jika data ril mengikuti garis diagonal.

\section{Uji Multikolinieritas}

Multikolinieritas berarti adanya hubungan yang sempurna atau pasti diantara beberapa atau semua variabel yang menjelaskan garis regresi. Model regresi yang baik seharusnya tidak terjadi korelasi diantara variabel independen. Cara mendeteksi ada tidaknya gejala multikolinieritasadalah dengan melihat nilai Variance Inflation Factor (VIF) atau faktor pertambahan 
ragam. Apabila nilai VIF lebih besar dari 10 maka terjadi multikolinieritas, sebaliknya apabila VIF lebih kecil dari 10 maka tidak terjadi multikolinieritas.

\section{Uji Heteroskedastisitas}

Tujuan asumsi Heteroskedastisitas adalah untuk menguji apakah dalam sebuah model regresi terdapat ketidaksamaan varians dari satu pengamatan ke pengamatan yang lain. Jika varians residual dari suatu pengamatan yang lain tetap, maka disebut homoskedastisitas dan jika varians berbeda, disebut heteroskedastisitas. Priyatno, (2012) menyatakan bahwa model regresi yang baik seharusnya tidak terjadi heteroskedastisitas. Pengujian heteroskedastisitas dalam kajian ini adalah dengan melihat penyebaran titik-titik pada grafik scatterplot yang kriterianya yaitu;

a) Jika ada pola tertentu seperti titik-titik yang ada membentuk suatu pola tertentu yang teratur (bergelombang, melebar kemudian menyempit), maka terjadi heterokedastisitas.

b) Jika tidak ada pola yang jelas, serta titik-titik menyebar diatas dan dibawah angka 0 pada sumbu $Y$, maka tidak terjadi heterokedastistas.

\section{Analisis Regresi Berganda}

Teknik analisis data yang digunakan dalam upaya menjawab masalah dan mencapai tujuan penelitian ini adalah analisis regresi berganda dengan rumus;

$Y=\alpha+\beta_{1} X_{1}+\beta_{2} X_{2}+\varepsilon$

Keterangan;

$\mathrm{Y}=$ Efisiensi dan efektivitas anggaran

$\alpha=$ Intercept

$\beta=$ Koefisien regresi 


$$
\begin{aligned}
& X_{1}=\text { Tugas ULP } \\
& X_{2}=\text { Wewenang ULP } \\
& \varepsilon=\text { Residual }
\end{aligned}
$$

\section{Pengujian Hipotesa}

Uji hipotesis dalam penelitian ini menggunakan uji t dengan tingkat signifikannya $5 \%$. Kriteria pengujiannya adalah; jika $t_{\text {hitung }}>$ $\mathrm{t}$ tabel maka $\mathrm{Ho}$ ditolak dan $\mathrm{Ha}$ diterima artinya terdapat pengaruhtugas dan wewenang ULP terhadap efisiensi dan efektivitas anggaran Pemerintah Provinsi Papua.Uji hipotesis lain yang digunakan adalah dengan menggunakan uji $\mathrm{F}$ dengan tingkat signifikan $5 \%$. Kriteria pengujiannya adalah; jika $F_{\text {hitung }}>F_{\text {tabel }}$ maka Ho ditolak dan $\mathrm{Ha}$ diterima artinya terdapat pengaruhtugas dan wewenang ULP terhadap efisiensi dan efektivitas anggaran Pemerintah Provinsi Papua.

\section{HASIL DAN PEMBAHASAN}

\section{Karakteristik Pokja ULP Provinsi Papua Berdasarkan Umur}

Karakteristik umur anggota Pokja ULP Provinsi Papua terdiri dari 9 kelas yang dimulai dari umur terendah yakni 32 tahun sampai tertinggi yaitu diatas 55 tahun seperti yang terlihat pada Tabel 1 dibawah ini.

\section{Tabel 1}

Karakteristik Umur Anggota Pokja ULP Provinsi Papua

\begin{tabular}{|c|c|c|}
\hline Umur (tahun) & Jumlah (orang) & Persentase (\%) \\
\hline $32-34$ & 3 & 6 \\
\hline $35-37$ & 4 & 8 \\
\hline $38-40$ & 5 & 10 \\
\hline $41-43$ & 14 & 28 \\
\hline $44-46$ & 10 & 20 \\
\hline $47-49$ & 7 & 14 \\
\hline
\end{tabular}




\begin{tabular}{|c|c|c|}
\hline Umur (tahun) & Jumlah (orang) & Persentase (\%) \\
\hline $50-52$ & 4 & 8 \\
\hline $53-55$ & 1 & 2 \\
\hline$>55$ & 2 & 4 \\
\hline Jumlah & $\mathbf{5 0}$ & $\mathbf{1 0 0}$ \\
\hline
\end{tabular}

Sumber : Data diolah, (2015)

Data pada Tabel 4.1 diatas menunjukan bahwa mayoritas responden penelitian ini relatif berusia diantara 41 sampai dengan 43tahun yakni sebanyak 14 atau $28 \%$. Gambaran karakteristik ini menunjukan bahwa secara keseluruhan responden dapat dikatakan berada pada usia produktif dengan mayoritasnya berusia antara 41 sampai dengan 43tahun yang secara tidak langsung menunjukan bahwa responden memiliki pengalaman kerja yang relative memadai.

\section{Karakteristik Pokja ULP Provinsi Papua Berdasarkan Pendidikan}

Pendidikan terakhir anggota Pokja ULP Provinsi Papua terdiri dari SMA, D3, S1 dan S2 seperti yang terlihat pada Tabel 2 dibawah ini.

Tabel 2

Karakteristik Pendidikan Anggota Pokja ULP Provinsi Papua

\begin{tabular}{|c|c|c|}
\hline Pendidikan & Jumlah (orang) & Persentase (\%) \\
\hline SMA & 21 & 42 \\
\hline D3 & 4 & 8 \\
\hline S1 & 16 & 32 \\
\hline S2 & 9 & 18 \\
\hline Jumlah & $\mathbf{5 0}$ & $\mathbf{1 0 0}$ \\
\hline
\end{tabular}

Sumber : Data diolah, (2015)

Sementara jika dilihat dari tingkat pendidikan terakhir maka akan terlihat bahwa mayoritas responden yang paling dominan memiliki pendidikan terakhir SMA yakni sebanyak 21 atau 42\%. Deskripsi karakteristik responden ini dapat diartikan bahwa karakteristik responden 
penelitian ini cenderung baik dalam merespon seluruh pernyataan penelitian yang diajukan oleh peneliti. Argumen ini diperkuat oleh tingkat pendiidkan terakhir responden yang mayoritasnya berpendidikan SMA di ikuti dengan Stara Satu dan bahkan ada yang berpendidikan strata dua.

\section{Karakteristik Pokja ULP Provinsi Papua Berdasarkan Jenis Kelamin}

Karakteristik anggota Pokja ULP Provinsi Papua berdasarkan jenis kelamin terdiri dari 2 kelas seperti yang terlihat pada Tabel 3 dibawah ini.

Tabel 3

Karakteristik Jenis Kelamin Anggota Pokja ULP Provinsi Papua

\begin{tabular}{|c|c|c|}
\hline Jenis Kelamin & Jumlah (orang) & Persentase (\%) \\
\hline Laki-laki & 35 & 70 \\
\hline Perempuan & 15 & 30 \\
\hline Jumlah & $\mathbf{5 0}$ & $\mathbf{1 0 0}$ \\
\hline
\end{tabular}

Sumber : Data diolah, (2015)

Gambaran karakteristik pada Tabel 3 diatas menunjukan bahwa responden secara keseluruhan lebih banyak didominasi oleh responden laki-laki yakni sebanyak 35 atau $70 \%$.

\section{Uji Instrumen Penelitian}

Uji instrument penelitian ini selanjutnya akan dibagi dalam 2 bagian yakni; uji validitas dan reliabilitas yang pembahasannya dibawah ini. Uji Validitas yaitu prosedur pengujian untuk melihat apakah alat atau pertanyaan yang dipakai dalam kuesioner dapat mengukur dengan cermat atau tidak. Uji validitas menunjukan sejauh mana tingkat efektivitas alat pengukur didalam melakukan pengukuran (Agusty, 2006). Uji validitas dalam penelitian ini menggunakan rumus korelasi Product Moment Person, dimana valid atau tidaknya instrumen dapat diketahui dengan membandingkan indeks korelasi dengan signifikan $5 \%$. Artinya 
bila probabilitas hasil korelasi lebih kecil dari 0.05 maka instrumen dinyatakan tidak valid dan sebaliknya, jika hasil korelasi lebih besar dari 0.05 maka instrumen dinyatakan valid.

Sementara pengujian reliabilitas dalam penelitian ini, pengujian reliabilitas menggunakan alpha cronbachs, dimana suatu instrumen dapat dikatakan reliabel jika memiliki nilai koefisien keandalan lebih besar atau sama dengan 0.5 artinya apabila $\alpha=0.5$ maka instrumen dapat dikatakan reliabel. Hasil pengujian kedua uji instrument penelitian terlihat pada Tabel 4 dibawah ini;

Tabel 4

Pengujian Instrumen Penelitian(Validitas dan Reliabilitas)

\begin{tabular}{|c|c|c|c|c|c|c|}
\hline Variabel & Indikator & Item & Korelasi & Ket & $\begin{array}{c}\text { Alpha } \\
\text { Cronbach }\end{array}$ & Ket \\
\hline \multirow{15}{*}{$\begin{array}{l}\text { Tugas ULP } \\
\qquad\left(\mathrm{X}_{1}\right)\end{array}$} & \multirow{4}{*}{ Ketua } & $X_{1.1}$ & 0.806 & Valid & \multirow{15}{*}{0.939} & \multirow{15}{*}{ Reliabel } \\
\hline & & $\mathrm{X}_{1.2}$ & 0.737 & Valid & & \\
\hline & & $X_{1.3}$ & 0.833 & Valid & & \\
\hline & & $X_{1.4}$ & 0.783 & Valid & & \\
\hline & \multirow{4}{*}{ Sekretariat } & $X_{1.5}$ & 0.875 & Valid & & \\
\hline & & $\mathrm{X}_{1.6}$ & 0.753 & Valid & & \\
\hline & & $\mathrm{X}_{1.7}$ & 0.829 & Valid & & \\
\hline & & $\mathrm{X}_{1.8}$ & 0.679 & Valid & & \\
\hline & \multirow{7}{*}{ Pokja } & $X_{1.9}$ & 0.832 & Valid & & \\
\hline & & $X_{1.10}$ & 0.859 & Valid & & \\
\hline & & $X_{1.11}$ & 0.842 & Valid & & \\
\hline & & $\mathrm{X}_{1.12}$ & 0.709 & Valid & & \\
\hline & & $\mathrm{X}_{1.13}$ & 0.628 & Valid & & \\
\hline & & $X_{1.14}$ & 0.594 & Valid & & \\
\hline & & $\mathrm{X}_{1.15}$ & 0.597 & Valid & & \\
\hline \multirow{9}{*}{$\begin{array}{l}\text { Wewenang } \\
\text { ULP }\left(\mathrm{X}_{2}\right)\end{array}$} & \multirow{5}{*}{ Menetapkan } & $X_{2.1}$ & 0.822 & Valid & \multirow{9}{*}{0.915} & \multirow{9}{*}{ Reliabel } \\
\hline & & $\mathrm{X}_{2.2}$ & 0.804 & Valid & & \\
\hline & & $X_{2.3}$ & 0.601 & Valid & & \\
\hline & & $\mathrm{X}_{2.4}$ & 0.689 & Valid & & \\
\hline & & $\mathrm{X}_{2.5}$ & 0.659 & Valid & & \\
\hline & \multirow{4}{*}{ Mengusulkan } & $X_{2.6}$ & 0.695 & Valid & & \\
\hline & & $X_{2.7}$ & 0.776 & Valid & & \\
\hline & & $\mathrm{X}_{2.8}$ & 0.732 & Valid & & \\
\hline & & $\mathrm{X}_{2.9}$ & 0.515 & Valid & & \\
\hline
\end{tabular}




\begin{tabular}{|c|c|c|c|c|c|c|}
\hline Variabel & Indikator & Item & Korelasi & Ket & $\begin{array}{c}\text { Alpha } \\
\text { Cronbach }\end{array}$ & Ket \\
\hline & \multirow{4}{*}{$\begin{array}{c}\text { Memberi } \\
\text { Sanksi }\end{array}$} & $X_{2.10}$ & 0.842 & Valid & & \\
\hline & & $\mathrm{X}_{2.11}$ & 0.735 & Valid & & \\
\hline & & $\mathrm{X}_{2.12}$ & 0.789 & Valid & & \\
\hline & & $\mathrm{X}_{2.13}$ & 0.612 & Valid & & \\
\hline \multirow{8}{*}{$\begin{array}{c}\text { Efisiensi \& } \\
\text { Efektivitas } \\
\text { (Y) }\end{array}$} & & $\mathrm{Y}_{1.1}$ & 0.802 & Valid & \multirow{8}{*}{0.921} & \multirow{8}{*}{ Reliabel } \\
\hline & & $\mathrm{Y}_{1.2}$ & 0.840 & Valid & & \\
\hline & Bıауа & $Y_{1.3}$ & 0.767 & Valid & & \\
\hline & & $\mathrm{Y}_{1.4}$ & 0.779 & Valid & & \\
\hline & \multirow{4}{*}{ Waktu } & $\mathrm{Y}_{1.5}$ & 0.749 & Valid & & \\
\hline & & $Y_{1.6}$ & 0.857 & Valid & & \\
\hline & & $Y_{1.7}$ & 0.827 & Valid & & \\
\hline & & $\mathrm{Y}_{1.8}$ & 0.849 & Valid & & \\
\hline
\end{tabular}

Sumber; Data diolah, (2015)

Hasil uji validitas dan realibilitas keseluruhan instrumen pada Tabel 4.5 diatas menunjukan hasil uji kolerasi lebih besar dari 0.5 dan memiliki nilai koefisien alpha cronbach's diatas 0.50 sehingga variabel pada tiap item pertanyaan dikatakan valid dan reliabel untuk dapat digunakan dalam pengolahan data selanjutnya.

\section{Analisis Regresi}

Hasil pengujian data penelitian ini menggunakan analisis regresi berganda dengan tujuan untuk mengananalisis pengaruh tugas dan wewenamg ULP terhadap efisiensi dan efektivitas anggaran di Provinsi Papuaseperti yang terlihat pada Tabel 5 dibawah ini.

Tabel 5. Hasil Pengujian Regresi Berganda

\begin{tabular}{|c|c|c|c|c|}
\hline Variabel & $\begin{array}{c}\text { Standardized } \\
\text { Coefficients }\end{array}$ & t hitung & Sig & Ket. \\
\hline Constant & 9.354 & \multicolumn{3}{|l|}{} \\
\hline Tugas ULP & 0.204 & 3.739 & .001 & Sig \\
\hline Wewenang ULP & 0.260 & 3.595 & .001 & Sig \\
\hline R Square & 0.633 & \\
\hline Adjusted R Square & 0.618
\end{tabular}

Tabel 5 (lanjutan) 


\begin{tabular}{|c|c|c|c|c|}
\hline Variabel & $\begin{array}{c}\text { Standardized } \\
\text { Coefficients }\end{array}$ & t hitung & Sig & Ket. \\
\hline $\mathrm{t}_{\text {tabel }}$ & 2.010 & & \\
\hline $\mathrm{F}_{\text {hitung }}$ & 40.560 & & \\
\hline $\mathrm{F}_{\text {table }}$ & 3.23 & \\
\hline
\end{tabular}

Sumber: Data diolah, (2015)

\section{Hasil Pengujian Hipotesis.}

Hasil analisispada Tabel 4.7diatas menunjukan bahwa tugas ULP dan wewenang ULP terbukti mempengaruhi tingkat efisiensi dan efektivitas anggarandi Provinsi Papua secara positif dan signifikan. Hal ini dapat dibuktikan dengan parameter atau koefisien regresi tugas ULP dan wewenang ULP yang menunjukan bahwa jika tugas ULP dan wewenang ULPmeningkat atau semakin baik maka tingkat efisiensi dan efektivitas anggaran di Provinsi Papua juga akan semakin meningkat. Dengan demikian dapat dijustifikasi bahwa dorongan peningkatan tugas ULP dan wewenang ULPakan meningkatkan tingkat efisiensi dan efektivitas anggaran di Provinsi Papua.

\section{Pengaruh Tugas Unit Layanan Pengadaan (ULP)Terhadap Efisiensi Dan Efektivitas Anggaran PadaUnit Layanan Pengadaan (ULP) Pemerintah Provinsi Papua.}

Hasil tersebut dibuktikan melalui pengujian hipotesis yang ditawarkan dalam penelitian ini. Hipotesis pertama menyatakan bahwa; tugas ULP berpengaruh terhadap efisiensi dan efektivitas anggaran di Provinsi Papua.Uji hipotesis dalam penelitian ini menggunakan uji $\mathrm{t}$ dengan tingkat signifikannya $5 \%$. Kriteria pengujiannya adalah; jika $t_{\text {hitung }}$ $>\mathrm{t}$ tabel maka $\mathrm{HO}$ ditolak dan Ha diterima artinya terdapat pengaruh tugas ULPatau wewenang ULP terhadap tingkat efisiensi dan efektivitas anggaran di Provinsi Papua. Asumsi lain yang digunakan adalah dengan membandingkan nilai $\rho$ probabilitas(sig), dimana jika nilai $\rho$ probabilitas (sig) $<0.05$ (level of significan) maka Ho ditolak dan Ha diterima, hal ini 
menunjukan terdapat pengaruh tugas ULPatau wewenang ULPterhadap tingkat efisiensi dan efektivitas anggaran di Provinsi Papua.

Berdasarkan hasil analisis ditemukan bahwa tugas ULP terbukti berpengaruh secara positif dan signifikan terhadap tingkat efisiensi dan efektivitas anggaran di Provinsi Papua. Hal ini ditunjukan dari nilai signifikansi sebesar 0.001 (probabilitas $<0.05$ ) dan nilai $t_{\text {hitung }}$ sebesar 3.739 sedangkan $t_{\text {tabel}} 2.010$ sehingga $t_{\text {hitung }}>t_{\text {tabel }}(3.739>2.010)$ yang berarti bahwa hipotesis pertama diterima. Hasil analisis diskriptif yang menggambarkan distribusi frekuensi jawaban responden tentang tugas ULP, terlihat bahwa indikator yang paling baik dalam menjelaskan variabel ini adalah indikator tugas tatausahaan/sekretariat ULP $\left(\mathrm{X}_{2}\right)$ yang terjabarkan melalui 4 pernyataan dengan nilai rata-ratanya 3.80 .

\section{Pengaruh Wewenang Unit Layanan Pengadaan (ULP)Terhadap Efisiensi Dan Efektivitas Anggaran PadaUnit Layanan Pengadaan (ULP) Pemerintah Provinsi Papua.}

Hipotesa kedua menyatakan bahwa wewenang ULP berpengaruh terhadap efisiensi dan efektivitas anggarandi Provinsi Papua. Berdasarkan hasil analisis ditemukan bahwa wewenang ULPterbukti berpengaruh secara positif dan signifikan terhadap tingkat efisiensi dan efektivitas anggarandi Provinsi Papua. Hal ini terlihat dari nilai signifikansi sebesar 0.001 (probabilitas $<0.05$ ) dan nilai $t_{\text {hitung }}$ sebesar 3.595 sedangkan $t_{\text {tabel }} 2.010$ sehingga $t_{\text {hitung }}>t_{\text {tabel }}(3.595>2.010)$ yang berarti bahwa hipotesis kedua diterima.Hasil analisis diskriptif yang menggambarkan distribusi frekuensi jawaban responden tentang tugas ULP, terlihat bahwa indikator yang paling baik dalam menjelaskan variabel ini adalah indikator tugas wewenang mengusulkan yang terjabarkan melalui 4 pernyataandengan nilai rata-ratanya 3.82 . 


\section{Pengaruh Tugas Dan Wewenang Unit Layanan Pengadaan (Ulp)Terhadap Efisiensi Dan Efektivitas Anggaran Pada Unit Layanan Pengadaan (ULP) Pemerintah Provinsi Papua.}

Hipotesa terakhir menyatakan bahwa tugas dan wewenang ULPsecara bersama-sama berpengaruh terhadap efisiensi dan efektivitas anggaran di Provinsi Papua. Berdasarkan hasil analisis ditemukan bahwa tugas dan wewenang ULP terbukti secara simultan berpengaruh positif dan signifikan terhadap efisiensi dan efektivitas anggaran di Provinsi Papua. Hal ini ditunjukan dari nilai signifikansi sebesar 0.000 (probabilitas $<0.05$ ) dengan nilai $F_{\text {hitung }}$ sebesar 40.560 sedangkan $F_{\text {tabel}} 3.23$ sehingga $F_{\text {hitung }}>F_{\text {tabel }}(40.560>3.23)$. Hasil pengujian ini membuktikan bahwa hipotesis ketiga diterima.

Temuan ini setidaknya akan mereduksi atau mengurangi peluang terjadinya pelanggaran yang muncul akibat dari lemahnyasistim dalampengadaan barang dan jasa pemerintah seperti yang disinyalir oleh KPK dan KPPU. Hal ini dapat terwujud karena beberapa hal yang selanjutnya oleh peneliti dikelompokan dalam 2 hal yakni dari sisi yurisis dan penataan organisasi, yang penjelasannya sebagai berikut;

a) Dari sisi yuridis, terdapat landasan hukum yang mengatur tentang pengadaan barang/jasa pemerintah yang telah diatur dalam Peraturan Presiden Nomor 70 Tahun 2012, dimana pemerintah daerah wajib membentuk Unit Layanan Pengadaan (ULP) paling lambat pada Tahun Anggaran 2014.Peraturan Presiden Nomor 70 Tahun 2012 selanjutnya diikuti oleh terbitnya Surat Keputusan (SK) Gubernur Provinsi Papua Nomor 188.4/49/Tahun 2014 tentang Pengangkatan Perangkat Organisasi dan Penetapan Tunjangan Profesi Perangkat Unit Layanan Pengadaan (ULP) Barang/Jasa Pemerintah Provinsi Papua.

b) Sementara penataan organisasi, kemudian diatur melaluiPeraturan Kepala LKPP No. 5 Tahun 2012 tentang Unit Layanan Pengadaan, 
dimana ULP dibentuk oleh Menteri/Pimpinan Lembaga/KepalaDaerah/Pimpinan Institusi. ULP sendiri bersifat permanendapat berdiri sendiri atau melekat pada unit yang sudah ada. Perangkat ULP ditetapkan sesuai kebutuhan yang paling kurang terdiri atas tugas/fungsi;Kepala, Ketatausahaan/Sekretariat danKelompok Kerja (Pokja).

Pembentukan ULP juga sekaligus menjawab permasalahan yang pernah diungkapkan ICW tahun 2005 yakni bahwa mekanisme pelaksanaan proyek yang memberikan keistimewaan kepada salah satu pihak melalui penunjukan langsung, praktik mark-up, pemerasan, penyimpangan kontrak dan proyek fiktif, seperti yang diungkapkan juga oleh Nurchana, Santoso dan Adiono, (2010) bahwa adaindikasi peluang "main mata"dalam pengadaan barang/jasadi Kabupaten Bojonegoro.

Dikatakan demikian karena berdasarkan prinsip-prinsip Pengadaan barang/jasa yang baik dilingkungan instansiPemerintahan sesuai dengan Keputusan Presiden RI wajib dilaksanakan sesuai dengan prinsip-prinsip sebagai berikut; efisien, efektif, bersaing, transparan, adil/tidak diskriminatif dan bertanggung jawab (Damayanti \& Hamzah,(2010). Sementara usaha penataan dan perbaikan organisasi khususnya di Provinsi Papua telah dilaksanakan dengan relatif baik. Hal ini terindikasi oleh adanya Standar Operasional Prosedur (SOP) di ULP Provinsi.

Secara konseptual, SOP merupakan bentuk konkret dari penerapan prinsip manajemen kualitas yang diaplikasikan untuk organisasi pemerintahan (organisasi publik). Tahap penting dalam penyusunan SOP adalah melakukan analisis sistem dan prosedur kerja, analisis tugas, dan melakukan analisis prosedur kerja yang juga dilengkapi dengan uraian tugas/pekerjaan (Susila, 2012). Implementasi SOP dan uraian tugas yang ada di ULP Provinsi ini seharusnya dapat meminimalisir peluang terjadinya pelanggaran-pelanggaran dalam proses pengadaan barang/jasa pemerintah seperti yang dikatakan diatas. 
Hal lainnya yang juga dilakukan di ULP Provinsi Papua yaitu penguatan Sumber Daya Manusia (SDM). Kebijakan ini dilakukan melalui; penempatan pegawai sesuai dengan formasi dan pangkat eselon, mengikutkan pegawai dalam kursus/pelatihan/sosialisasi terkait dengan aturan-aturan pengadaan barang/jasa pemerintah, disamping itu perlu menjalin hubungan dengan ahli-ahli pengadaan di lingkungannya maupun diluar lingkungan organisasi serta yang akan dilakukan adalah pengangkatan pegawai yang masih berstatus honor atau kontrak menjadi pegawai negeri di ULP Provinsi Papua.

Temuan penelitian ini sejalan dengan hasil kajian-kajian empiris oleh; Kartikaningrum, (2007) mengatakan bahwa terdapat hubungan transparansi, efektifitas dan efisiensi terhadap proses pengadaan barang.Peneliti lainnya; Wijaya, Indryani dan Putri, (2010) menyatakan bahwa secara parsial maupun simultan, variabel biaya dan waktu berpengaruh signifikan terhadap kinerja dan efisiensi pengadaan barang dan jasa.

Hasil penelitian ini juga sejalan dengan pendapat Tasori, (2014) yang merekomendasikan pembentukan ULP provinsi dengan status yang lebih mandiri agar tugas dan perannya dapat berjalan dengan baik dan sesuai dengan ketentuan peraturan yang berlaku sehingga dengan sendirinya akan mampu menciptakan keefektifan dalam proses pengadaan barang dan jasa.Hasil kajian empiris lainnya yang sejalan dengan temuan penelitian ini juga diungkapkan oleh Noviyanti, (2014) yang menyatakan bahwa Layanan Pengadaan Secara Elektronik (LPSE) dan pembentukan Unit Layanan Pengadaan (ULP) mampu mendorong terciptanya efisiensi APBN maupun APBD.

\section{KESIMPULAN DAN SARAN}

\section{Kesimpulan}

1) Secara parsialtugas ULP terbukti berpengaruh secara positif dan signifikan terhadap tingkat efisiensi dan efektivitas anggaran di 
Provinsi Papua. Hal ini ditunjukan dari nilai signifikansi sebesar 0.001 (probabilitas $<0.05$ ) dan nilai $t_{\text {hitung }}$ sebesar 3.739 sedangkan $t_{\text {tabel }}$ 2.010 sehingga $t_{\text {hitung }}>t_{\text {tabel }}(3.739>2.010)$ yang berarti bahwa hipotesis pertama diterima.

2) Secara Parsial wewenang ULP terbukti berpengaruh secara positif dan signifikan terhadap tingkat efisiensi dan efektivitas anggaran di Provinsi Papua. Hal ini terlihat dari nilai signifikansi sebesar 0.001 (probabilitas < 0.05) dan nilai $t_{\text {hitung }}$ sebesar 3.595 sedangkan $t_{\text {tabel}} 2.010$ sehingga $t_{\text {hitung }}>t_{\text {tabel }}(3.595>2.010)$ yang berarti bahwa hipotesis kedua diterima.

3) Secara simultan dijelaskan bahwa tugas dan wewenang ULP terbukti berpengaruh positif dan signifikan terhadap efisiensi dan efektivitas anggaran di Provinsi Papua. Hal ini ditunjukan dari nilai signifikansi sebesar 0.000 (probabilitas $<0.05$ ) dengan nilai $F_{\text {hitung }}$ sebesar 40.560 sedangkan $F_{\text {tabel}} 3.23$ sehingga $F_{\text {hitung }}>F_{\text {tabel }}(40.560>3.23)$.

\section{Saran}

1. Untuk menjamin berjalan efisiensi dan efektifitas dalam Unit Layanan Pengadaan Provinsi Papua maka diperlukan pengawasan atau pemantauan yang intensif baik dari masyarakat dan LSM seperti ICW (Indonesia Corruption Watch). Perlunya pengawasan masyarakat dan LSM tersebut, karena dua aktor tersebut memiliki peran yang dianggap paling bagus dan netral dalam pengadaan barang/jasa, sehingga tujuan e-procurement nantinya dapat berjalan dengan baik dan tanpa ada kecurigaan.

2. Perlu ditingkatkan pelaksanaan komunikasi baik antar Satuan Kerja Perangkat Daerah (SKPD) maupun peserta penyedia barang dan jasa/masyarakat secara luas dalam pelaksanaan e-procurement dimana informasi harus disampaikan dengan sejelas-jelasnya, setepat-tepatnya dan seakurat mungkin serta dapat dipahami agar tidak terjadi penyimpangan-penyimpangan. 
3. Dalam rangka pelaksanaan tugas dan wewenang yang diemban ULP wajib memperhatikan peraturan-peraturan yang berlaku, serta memperhatikan, mengevaluasi sumber daya aparat yang berada pada ULP sehingga selalu diupayakan peningkatan-peningkatan dan kemampuan agar dalam pelaksanaan setiap tugas dan wewenang dapat dijaankan dengan baik yang berkaitan dengan pelaksanaan eprocurement maupun tugas dan wewenang lain dapat dihandalkan sebagai suatu sumber kekuatan yang positif dalammencapai efisiensi dan efektifitas ULP.

\section{DAFTAR PUSTAKA}

Adi S, 2012. Kajian Pembentukan ULP Barang/Jasa Pemerintah di Pemerintah Kota Bekasi, Jurnal AKP, Vol 1, No. 2, Agustus 2012.

Agusty F, 2006. Metode Penelitian Manajemen: Pedoman Penelitian Untuk Penulisan Skripsi, Tesis Dan Disertasi IImu Manajemen, Edisi Kedua,Badan Penerbit Universitas Diponegoro, Semarang, Semarang.

Anggun R.A., 2013. Pengaruh Penggunaan Sistim Pengadaan Secara Elektronik (SPSE) Terhadap Efisiensi Kerja Pegawai Dalam Bidang Pengadaan Barang/Jasa Pada ULP dan LPSE di Pemerintah Kota Cimahi, Skripsi, Universitas Pendidikan Indonesia.

Arindra R.A.N., Bambang S.H., Romula A., 2010. Efektifitas EProcurement Dalam Pengadaan Barang/Jasa (Studi terhadap Penerapan E-Procurement di Kabupaten Bojonegoro), Jurnal Administrasi Publik, Vol 2, No. 2, 2010.

Astri D., dan Ardi H., 2010. Pengaruh E-Procurement Terhadap Good Governance, Penelitian Mandiri, Universitas Trunojoyo.

Dwiyanto, A. 2005. Mewujudkan Good Governace Melalui Pelayanan Publik, Jogyakarta: Gajah Mada University Press.

Farisa N. 2014. Peran LPSE Dalam Meningkatkan Efisiensi Pengadaan Barang/Jasa Pemerintah, Penelitian Mandiri, STAN Tangerang Selatan. 
Habib, B. 1996. Pengaruh Dimensi Anggaran Terhadap Sikap Manajer Mengenai Anggaran dan Terhadap Efektifitas Pelaksanaan Anggaran, Thesis tidak dipublikasikan, Program Pasca Sarjana, Universitas Padjajaran Bandung.

Horngren, C.T., George F., Srikant M.D., 2000. Cost Accounting, a Managerial Emphasis, Tenth Edition, Prentice Hall International Inc.

Kajian Ringkas, (2012) Evaluasi Peraturan Menteri Negara PPN/Kepala Bappenas No. 005/M.PPN/10/2007, Tentang Organisasi dan Tata Kerja Kementerian Negara PPN/Bappenas (Unit Layanan Pengadaan (ULP) dan Tata Kerja Kementerian PPN/Bappenas), Biro Hukum Kementerian PPN/Bappenas, Mei 2012.

Keppres No. 80 Tahun 2003, Tentang Pedoman Pengadaan Barang dan Jasa Pemerintah.

Majalah Kredibel, (2012) Majalah Pengadaan Indonesia, Edisi 03, JuliOktober 2012.

Nindy, S. 2013 Efektivitas Monitoring dan Evaluasi Terhadap Reformasi Pengadaan Barang/Jasa di Kabupaten Kulon Progo, Skripsi, Universitas Muhhamadiah yogyakarta.

Ozcan, Y.A. 2008. Health Care Benchmarking and Performance Evaluation, Springer, New York.

Peraturan Kepala LKPP No. 5 Tahun 2012, Tentang Unit Layanan Pengadaan.

Peraturan Pemerintah Nomor 41 Tahun 2007,Tentang Organisasi Perangkat Daerah.

Peraturan Presiden Nomor 54 Tahun 2010, tentang Pengadaan Barang/jasa Pemerintah.

Peraturan Presiden Nomor 70 tahun 2012,Tentang Pedoman Pengadaan Barang/Jasa Pemerintah

Prabowo, A. 2012. Kredibel Majalah Pengadaan Indonesia, Edisi 03 JuliOktober 2012.

Priyatno, D. 2012. Belajar Cepat Olah Data Statistik Dengan SPSS, Andi, Yogyakarta. 
Sunyoto, D. 2012. Analisis Validitas \& Asumsi Klasik, Gava Media, Yogyakarta.

Surat Keputusan (SK) Gubernur Provinsi Papua Nomor 188.4/49/Tahun 2014, Tentang Pengangkatan Perangkat Organisasi dan Penetapan Tunjangan.

Tasori. 2014. Analisis Penerapan Good Governance Dalam Proses Pengadaan Barang dan Jasa Provinsi Kepulauan Riau tahun Anggaran 2013, Naskah Publikasi Skripsi, Universitas Maritim Raja Ali Haji Tanungpinang.

The Ling Gie dan Miftah Thoha. 1978. Cara Bekerja Efisien, Yogyakarta, Karya Kencana.

Thoha. 2004. Perilaku Organisasi, Jakarta: PT. Raja Grafindo Persada.

Udoyono. 2012. E-Procurement Dalam Pengadaan Barang dan Jasa Untuk Mewujudkan Akuntanbilitas di Kota Yogyakarta, Jurnal Studi Pemerintahan, Vol. 3, No. 1, Februari 2012.

Undang-Undang Republik Indonesia Nomor 58 Tahun 2005, Tentang Keuangan Daerah.

Wahyu Hari Wijaya, Retno Indriyani dan Yusronia Eka Putri, (2009) Studi Penerapan E- Procurement Pada Proses Pengadaan di Pemerintah Kota Surabaya, Penelitian Mandiri, ITS Surabaya. 